\title{
The Mexican Third Sector of the Media: The Long Run to Democratise the Mexican Communication System.
}

\author{
Rodrigo Gómez
}

\author{
Universidad Autónoma Metropolitana-Cuajimalpa Ciudad de México, México. \\ rgomez@correo.cua.uam.mx
}

\begin{abstract}
This article addresses the structural historical conditions of the Mexican communication system (MCS) in relation to the process of its democratisation. In order to analyse this process of democratisation, the research focused on the struggles of the third sector of the media - citizen/community/popular/free/alternative/radical/indigenous - to find room in that communication system. The aim was to highlight the structural inequality faced by this sector when compared with the hegemony of the private/commercial - or first - sector. From a normative perspective, a democratic and pluralistic communication system must have fair and equitable conditions among the three media sectors - private, public and citizen - with the aim of generating horizontal public spheres as a plural network of spaces for public conversation and deliberation on common issues.
\end{abstract}

Keywords: Citizen Media, Latin America, Media Policy, Media Systems, México

Acknowledgement: I am grateful to Ben Birkinbine and Graham Murdock for their careful review of this article and their feedback. This research was funded by the Communication Department of UAM-C.

\section{Introduction}

The Mexican media (communication) system has been characterised in the orbit of clientelism (Hallin and Papathanassopoulus 2002) and limited pluralism models (Soledad Segura and Waisbord 2016) with liberal aspirations, and, at the same time, as one of the most concentrated systems in the world (Gómez 2016). However, since the end of the twentieth century, the Mexican communication system has exhibited signs of change, and of edging toward democratisation. These changes are in a way parallel to a wider process of political democratisation that Mexico has experienced at the same time (Woldenberg 2015). However, the dominance of the private sector in the Mexican communication system (MCS) remains unbalanced when compared with the third sector of the media, which continues in the margins and at grassroots levels.

It is important to understand that the third sector of the media had no legal standing in the former Mexican Radio and Television Industry Act of 1960, a position altered by the 2014 Telecommunications and Broadcasting Act. ${ }^{1}$ In fact, for many years the majority of these media sources operated without licences, despite making applications or having activated procedures with the Ministry of Communications and Transports, the federal institution charged with granting those licences. Thus, the struggle to gain access to operate media outlets, particularly community radio sta-

1 To understand the process and the general specificities of that new media policy, see Meneses and Bravo (2015). 
tions, has been complicated and has literally involved a battle with federal authorities, local politicians and commercial radio stations (Calleja and Solis 2007). Indeed, these small but long-existing radio stations have been criminalised and persecuted by the federal authorities, who were induced by strong pressure from the mainstream owners calling these small stations clandestine, pirates and guerrilla instruments (Romo 1990).

The present article analyses three main historic communicative battles fought by the Mexican media's third sector: a) recognition of the sector as citizen/community media; b) exercise of the freedom of expression; and c) the practice of communicative citizenship. These battles will be discussed in the following sections, with the aim of highlighting both key historical moments and the broader structural characteristics that established the context for those battles.

It is important to underline in this introduction that the processes involved in media reform in general and the issuing of the Mexican 2014 Telecommunications and Broadcasting Act specifically should be read in the context of the emerging democratic processes of Mexico, and in a wider sense at the Latin American level. From 2000-2017, media and telecommunications in Latin American have undergone many reforms, and the debates surrounding those reforms have largely come from two dominant perspectives: market logic vs. communication and social rights. Importantly, in some cases these reforms and debates have been accompanied by media movements (Soledad Segura and Waisboard 2016). Thus, this article proceeds from the assumption that changes in the Latin American communications systems are essential for understanding broader democratisation processes in the region. In addition, these reforms have been advanced and can be understood within the context of broader political trends in the region, most notably within those countries associated with the Pink Tide - Argentina, Bolivia, Ecuador, Uruguay and Venezuela (Artz 2017; Badillo, Mastrini and Mariategui 2015).

To close this introduction, it has to be pointed out that the third sector of media in Mexico has largely been linked to the indigenous and peasant communities, urban collectives and social movements. Thus, in this article's view, this sector has been important in five areas: a) communication of proximity; b) cultural survival and linguistic resistance; c) media education; d) social justice and social development; and e) freedom of expression.

\section{Theoretical Starting Points}

The study of the third sector media has been growing significantly during the first two decades of the twenty-first century (Atton 2015; Downey and Fenton 2003; Downing 2001; Howley 2009; Milan 2010; Rodríguez et al. 2009). However, in Latin America, there has been an important tradition of research and activism in this matter since the 1970s (Beltran 1976; Kaplún 1985; Reyes-Matta 1983). These studies have addressed how third-sector media sources can generate social development, political and cultural resistance, the recognition of human rights, counter-information, a counter-public, cultural diversity and education in marginal communities.

As other authors have pointed out, the third sector of the media includes a set of media outlets that have been defined in different ways (Atton 2015; Downing 2001) according to specific historical and regional contexts and the theoretical frameworks within which they were observed. That media sector is related largely to community, non-profit, citizen, radical, popular, free, alternative and indigenous media, among others. Thus, the idea of the third communication sector is very helpful for linking these heterogeneous experiences and approaches, and for addressing them in an 
open field. At the same time, it is extremely useful to identify the historic dominance or hegemony of the other two sectors of the media: the commercial (first) sector and the public (second) sector.

Fuchs similarly describes "civil society media" in a way that connects with the third sector when he claims, "civil society media are full parts of the public sphere [...] Citizens run, own, and control civil society media as common projects. They express alternative points of view on the level of culture and have alternative organisation models at the level of political economy" $(2015,330)$.

Another point that must be established here is that, from Habermas's perspective (1996), the research indicates that the development of the third sector of the media as horizontal public spheres - a plural network of spaces for public conversation and deliberation on common issues (Dahlgren 2006) - is essential to a fully democratic society. At the same time, the present article agrees with Dahlgren about the relation between public sphere and citizens: he establishes that "the public sphere does not begin and end when media content reaches an audience: this is but one step in larger communication and cultural chains that include how the media output is received, made sense of and utilized by citizens" $(2006,274)$.

The starting point of this research addressing the media/communication third sector follows the idea that this sector comprises a range of different communication experiences that are not commercial or public-institutional. Thus, they do not necessarily have any commercial or governmental interest. They are media sources that aspire to reflect the different expressions of organised civil society, and expressions that the other sectors do not encompass (Sáez 2008). The strong point of this approach, as Sáez points out, is a strategic one, because the visibility of the third sector of communication lays claims for a media space and highlights the incomplete nature (2008, 77-79) and contradictions of the communications systems operating within global capitalism.

Members of AMARC have some definitions of community media drawn from their own experiences, which could prove useful to illustrate the wide range of experiences that we are discussing. For example:

The historical philosophy of community radio is to use this medium as the voice of the voiceless (landless peasants, urban shack dwellers, impoverished indigenous nations, trade unions, etc.), the mouthpiece of oppressed people (be it on racial, gender, or class grounds) and generally as a tool for development [...] Community radio is defined as having three aspects: non-profit making, community ownership and control, community participation [...] It should be made clear that community radio is not about doing something for the community, but about the community doing something for itself, i.e. owning and controlling its own means of communication. (Mtimde et al. 1998, 14)

This research follows the specificities that Clemencia Rodríguez gives to the concept of 'citizen media' by focusing on the cultural and social processes it provokes when local communities or collectives appropriate communication and information technologies: 
Citizen media are radio stations, community televisions, Internet initiatives. All media that open communicative spaces where men, women and children learn to build their own languages, codes, signs and symbols. Thus, they [are] empowered to name the word in their own terms. Citizen media activate processes from individuals to communities that resignify their contexts and identities [...] Citizen media are the media that are used by citizens to trigger communication processes that contribute to shape their local communities. (Rodríguez 2009, 18)

In other words, this article understands the third sector as stemming from its citizenship specificity to empowered individuals, communities, collectives and social movements, and the way they use communication and information as an expression of citizenship to consolidate or build democratic societies. It must be said that, from this research, this relationship between citizenship and media/communication has to be read or understood while considering some minimal democratic conditions where individuals and communities are subjects with rights and able to exercise their citizenship. From this perspective, the third sector of communication is recalibrating, in specific contexts, the dominant social relations of power, where communication is experienced and takes a central role in terms of its power in political and sociocultural arenas (Castells 2015).

Having established that in this article we understand the third sector of the communication system as a significant social agent, it is important to incorporate the process of structuration that shapes the MCS and its social agents. As Mosco has argued, "social action takes place within the constraints and the opportunities provided by the structures within which action happens. We can bring about social change and make history but only under the terms that social structures enable" $(2009,16)$.

This research deals with this power structure-agency dualism because "structures constrain individuals by using economic, political and cultural power" (Ibid., 209). Thus, this article addresses the "long run of the third sector media in the MCS" from the historical structural analysis of the political economy of communication (Golding and Murdock 2000).

Another aspect that should be considered is the process of digitisation that is affecting the communications systems, as they were known before technological convergence. Because of these changes, there is evidence that we are observing a recalibration of communication power (Khalil and Downing 2016), where the citizen/community media/communication is experiencing an important change from closed analogue practices to open and multiple digital ones. This new context provides important potential to the citizen/community media outlets as counterhegemonic agents to expand their content-production possibilities because of the low cost of digital communication technologies. More significantly, there is now a greater range over which to disseminate the media's symbolic content. In the past, the primary method for reaching a broader audience for counter-hegemonic symbolic content was to broadcast airwaves to local communities, but now these media outlets can use digital technologies to distribute their messages across multiple platforms, thus obtaining greater symbolic recognition in the public sphere (Fraser and Honneth 2003) as subaltern counter-public spheres (Downey and Fenton 2003).

At the same time, this new digital scenario increases the possibilities of the third sector using the platforms to operate telecommunications networks and build allianc- 
es with other kinds of collectives, such as hackers and free and open source software agendas. This digital and convergent situation is opening up the third sector of the communication field in so many ways that it must be included in the study of citizen media/communications, particularly with respect to intersections and interactions with social movements. In that regard, this article notes that in understanding the development of the third sector, analysis needs to see it as the outcome of the continuous interplay between embedded structures and forms of agency pressing for change.

Mexico is one of the countries that has many citizens living abroad as immigrants, specifically in the United States of America, and the only way that these diaspora communities can maintain links with their roots, languages and families is the local community radio stations that can now provide webcasts via the Internet. As such, the convergence of media with digital platforms has enabled some degree of translocalism, especially when accessing community/citizen media (Hayes 2018).

Finally, this research follows the call of the Latin American sociologist Pablo González (2013), who points out the challenges of critical thought of confronting the communication and information sciences' dominant focus on achieving the objectives and aims of corporate capitalism and its organisational systems for profit maximisation and minimisation loss. In fact, the present structural-historical research approaches the study of the third sector by exploring alternative means of understanding the communications systems and their relationship with democratic participatory practices and non-profit commercial logics, which attempt to struggle against and escape the hegemonic structuration of corporate, global capitalism.

\section{Managed Collusion}

This section provides a brief history of the Mexican radio industry. Mejía (1989) documented the origins of the radio industry in Mexico as being related to commercial experiences in the 1920s. The consolidation of the most important groups involved in that early broadcasting industry started in the 1940s and continues today. The broadcaster barons ${ }^{2}$ secured important guarantees from the government; for example, that they could obtain and exploit their commercial licences for 50 years (lbid.) and operate for 20 years without a specific Act in place. In 1940, there were 113 commercial licences and five state permissions; fewer than $5 \%$ of the total licences were in the second sector of the media (Ibid.). Since then, the state has promoted political and legal conditions to develop a concentrated and closed commercial broadcasting model. That model certainly collaborated with their radio programming content and advertisers to incorporate Mexican urban areas into the consumer capitalism society of the middle twentieth century. For example, in 1941, the Cámara Nacional de la Industria de la Radio (CIR) was founded, and since then this organisation has been the voice of the first sector of the media and has protected and lobbied on behalf of its interests.

It is important to recall that the Mexican government implemented a strong procommercial broadcasting policy, but with the particular aim to establish an alliance between the ruling party - the Partido Revolucionario Institucional (PRI) - and the commercial broadcaster barons. The unwritten deal was very clear: the barons re-

${ }^{2}$ According to Sosa (2009), since the first licences were issued, there have been eight dominant family groups that have been controlling the national radio market in Mexico. Those groups are: Radio ACIR, Radio Formula, Radio Centro, Televisa Radio, MVS Radio, Radio ABC, NRM Comunicaciones and Grupo Imagen. 
ceived licences and, in return, the commercial radio stations supported the government, and particularly the president of the republic (Sosa 2011). The state and government radio networks did not present any threat to the commercial radio networks in terms of national scope and advertising competition.

However, this unwritten deal and alliance produced some tensions between the $\mathrm{CIR}$ and the different governments, because the former always pushed to maintain their privileges and to protect their economic interests against any reform or public policies related to the broadcasting industry. At the same time, the latter maintained or issued some specific rules that gave them discretional power to cancel or issue licences as a form of influence or negotiating card with the radio/media owners.

The 1960 Federal Radio and Television Act is a clear example of how the broadcasting barons pushed and negotiated to build a legal framework that protected their economic interests and benefits. Indeed, the Act reinforced, protected ${ }^{3}$ and expanded those interests, and did not place any restrictions on media ownership, whether of horizontal, vertical or cross-ownership concentration. In addition, the Mexican communication authorities only had two kinds of licences: commercial concessions and cultural/educative not-for-profit permissions. The 1960 Act stipulated that not-forprofit broadcasting permissions were issued for the operation of "official stations" by bodies subordinated to the centralised federal public administration, state and municipal governments and public educational institutions. Thus, citizens, communities and indigenous populations were excluded in the legal framework that shaped the MCS during the second half of the twentieth century. In addition, public service broadcasting was not a priority for the Mexican political ruling class during those years (Ortega 2006). Therefore, the 1960 Act could be characterised as a media policy oriented to develop a structurally hegemonic and concentrated commercial broadcasting clientelism model, with marginal and peripheral state cultural and educative (public) broadcasting networks.

To be historically fair, the 1960 Act was a clear public policy in relation to the Mexican political system's view of those years - with their pro-national private investors and political clientelism practices - and its own undemocratic stamp (Smith 2001). Consequently, it is difficult to think that the Mexican government and its ruling PRI party would issue a democratic Act that considered different actors to those stipulated in that media framework. The main issue here, in historic terms too, is that the Act was not reformed until 2006, and that reform undermined the third sector of the media (Sosa 2009). In other words, the social relations of power in terms of the structure of the MCS were strongly dominated by the commercial first sector over the course of 75 years.

Despite these circumstantial and structural limits, different expressions of the third sector of the media began to emerge and operate in the 1960s. For example, Calleja and Solis (2007) report that Radio Huayacocotla and Radio Teocelo, in the state of Veracruz, have been on the air since that time. At the same time, they identify some stations that operated in the 1970s and 1980s without licences.

In the case of Radio Huayacocotla and Radio Teocelo, it is important to emphasise that they received permissions from the federal government, but were an unusual exception. Their authorisation seems more like a test from the government to determine the potentials, challenges and threats that could generate these kind of stations, rather than the beginning of an official policy of granting licences to communi-

${ }^{3}$ The industry acknowledged forbidding foreign investment and ownership in broadcasting. Before this Act, US investors were highly active in the industry. 
ties and citizens. After those permissions were granted, no other community received that privilege until the beginning of the twenty-first century. In addition, it has to be said that the broadcasting power of those stations was very limited, constrained to just a couple of square kilometres. For example, in the case of Radio Huayacocotla, the station operated with $2390 \mathrm{kHz}$ and 500 watts in shortwave, and Radio Teocelo operated in the $1490 \mathrm{kHz}$ AM band with 250 watts.

The structural history of the third sector in Mexico is linked to the different experiences of small alternative radio stations from the second half of the twentieth century onwards. Some of those first initiatives were part of rural literacy programmes, called school radios, in the state of Hidalgo. According to Calleja and Solis (2007, 61-64), alternative radio during those early years was short-lived because of the technological, financial and legal difficulties involved in operating, and in being recognised by the state authorities.

\subsection{Mexican Singularity (Radios Indigenistas)}

From the late 1970s until the 1990s, several radio stations emerged who had obtained the licence required for permission, but who also came close to the orbit of the third sector and, paradoxically, were launched and promoted from a government office, the National Indigenous Institute ${ }^{4}$ [Instituto Nacional Indigenista or simply INI]. The main aim at the beginning of this public policy was to promote indigenous assimilation and literacy through the Spanish language. These stations were called $R a-$ dios Indigenistas. In fact, the Radios Indigenistas are an interesting example of how a governmental and paternalistic initiative may be re-appropriated and co-opted by indigenous communities. These stations migrated from a vertical institutional structure to a horizontal structure, which characterises the practices of citizen/community radio.

The idea of these radio stations, according to official INI documents, was to increase connectivity to the geographically isolated communities that lacked mass media. Thus, their objectives were to provide a communication service to their inhabitants and promote, preserve and spread indigenous cultures and traditions. At the same time, the INI thought that the radio stations could be an important tool for reinforcing their institutional work (INI 1995, 249).

Mexican scholars have pointed to this example to attract attention to the fact that some concepts and characterisations in social science, and particularly in communication and media studies, have to be flexible and dynamic. If some definitions of community or indigenous media are followed, regardless of their institutional links and origins, some scholars would argue that these experiences could or must be excluded. Furthermore, these Radios Indigenistas have been key players for understanding the different communication experiences that could emerge according to the contradictions and inequities of Mexican society and its political system (CastellsTalens 2011). In that vein, Ramos $(2016,182)$ sustains that these radio stations "operate in a tensioned field between institutional federal policies, the local power authorities and the necessities and interests of indigenous towns".

4 This federal government office changed its name during the Vicente Fox administration (2001-2006) to the National Commission for the Development of Indigenous Towns [Comisión Nacional para el Desarrollo de los Pueblos Indígenas] with the aim to change the approach and policies of the Mexican government towards indigenous communities and towns. The change was clearly forced by the Zapatista uprising. This office was launched in 1949 by the federal government with the mandate to generate fair relations between the 56 ethnic groups of Mexican society. 
It is important to note that even though the Radios Indigenistas comprise a network of radio stations and are part of an institutional public policy that tried to implement some general guidelines and coordinated plans of action, they are not homogenous and have been developed according to the different practices and appropriation processes of every community involved. These uses and appropriations of radio by communities changed some initial guidelines of the INI, and the institute "embraced ideas of cultural sensitivity and respect for indigenous cultures" (Castells-Talens and Ramos 2013, 180) in their languages. Another important aspect of these stations was that the majority of their staff came from local communities and spoke indigenous languages. In this regard, these radio stations have been used as communication and audiovisual production schools for those communities. In addition, the communities started to use the stations for their own interests. For example, these stations included discussion about local issues, used the broadcasts as a community service and played indigenous music. As Castells-Talens and Ramos state: "While these interactions took place in the context of asymmetrical power relations, indigenous broadcasters and listeners found a variety of ways to exert a degree of popular agency" (lbid.).

The first Radio Indigenista was launched in 1979 - "La voz de la Montaña" in the state of Guerrero (INI 1995) - and 20 additional stations were opened in states with an important presence of indigenous populations from then until 2003. As we know, the indigenous towns in Mexico have experienced marginal socio-economic conditions, and empirical research has proven that the radio stations have been helping to develop social, cultural, political and health processes in those communities (Castells-Talens and Ramos 2013; Cornejo 2010).

Another important aspect that has to be taken into account is that the radio stations are the most important form of communication for these communities because a significant proportion of their populations are illiterate, and some of them do not speak Spanish. Thus, these radio stations have become central in these communities' cultural everyday life because the other two sectors of the media do not speak their languages or consider them a market audience (del Val et al. 2010).

The shift of these radio stations from paternalistic state media to public service and citizen/community media is vitally important. However, there are threats to these stations' continued operation if they remain under the umbrella of the federal government office, the Comisión Nacional de los Pueblos Indios (CDI). According to Calleja (2016), since 2015 the CDl's institutional communication policies have shifted $180^{\circ}$, because the Sistema Nacional de Radios Indigenistas came under the authority of the communication office of the CDI. Consequently, this historically important radio network has been used as the voice of the federal government. At the same time, its budget has been cut and there have been layoffs of indigenous radio workers. This twist is particularly noteworthy because these radio stations reach 21 million potential listeners -5.5 million of them are indigenous people that speak indigenous languages - in 15 states of the Republic, broadcasting in 31 indigenous languages. As Calleja argues, the Radios Indigenistas are under attack; an attack that threatens one of the biggest cultural collections and expressions of the Mexican indigenous towns, or, put simply, Mexican cultural heritage (2016).

Therefore, these Radios Indigenistas are an exemplary case in the history of the Mexican third sector. They are just one expression amongst many other examples, and they are lucky to operate without being harassed, especially because the majority of the Mexican media's third sector has been pursued and criminalised by the state and the commercial broadcasting industry. 
In summary, it may be established that within this structure the Mexican third sector developed in two ways: Government sponsorship of indigenous radio from the 1970s onwards, and Independent stations with no legal status - operating without a licence or formal access to the spectrum.

\title{
4. The Zapatista Intervention
}

One crucial point in the history of the third sector media in Mexico was the uprising of the Ejército Zapatista de Liberación Nacional (EZLN; the National Zapatista Liberation Army). This is largely for two reasons: 1) the EZLN fought for recognition, at a constitutional level, for the access of indigenous communities to broadcasting licences without government intermediation as the former INI; and 2) they proclaimed the importance of the free media - the third sector - for achieving some balance in the unequal and concentrated MCS as a condition for expanding Mexican democracy.

In 1996, the EZLN signed the San Andrés agreements with the Mexican federal government, which included in the national agenda the right of indigenous towns and communities to have access to communications licences and to operate their own means of communication, including broadcasting, telephones, the press, computers, satellite access, and the Internet. In 2001, in the context of a constitutional reform regarding "indigenous rights and culture", the legislative amendment reads as follows:

\begin{abstract}
Expand communication networks that allow the communities integration through the construction and enlargement of telecommunications and communication routes. Establish conditions for the indigenous communities and towns to get access operate and manage communication media, in the terms that the specific Act mandates. (Diario Oficial de la Nación 2001)
\end{abstract}

However, these important additions at constitutional level, inspired by the negotiations and pressures of the EZLN, were not reflected in the Radio and Television Federal Act of 2001 to 2014. In other words, the secondary Act was not amended to recognise that constitutional mandate.

At the same time, during those years and at the grassroots level, the EZLN generated or prompted the uprising of different experiences of free/community/citizen media (Magallanes 2011; Rovira 2014). For example, during 2001, after the defeat of the PRI by Vicente Fox as president of the republic, and the subsequent offer to solve the problem of Chiapas "in five minutes", the EZLN started the "Earth's Colour March" [La Marcha del Color de la Tierra] from Chiapas to Mexico City. The aim of the march was to push for recognition of the San Andrés Agreements at the constitutional level, which would grant constitutional recognition of indigenous rights and culture. During that 15-day journey, the EZLN called on the third sector of the media at all levels - local, national, regional and global - to cover the march involving EZLN delegates and different sectors of Mexican society, as a way to break the siege of the mainstream media agenda. In particular, these experiences allowed community and citizen media groups to spread the message of the Zapatistas by way of the audiovisual productions made by the "Medios Libres" movement. For example, Indymedia Chiapas and Indymedia Oaxaca were key players in providing information about the Zapatista's activities through local small community radios within Mexico, but also to 
citizen and community media stations on an international scale as well. In this moment, the "Earth's Colour March" was also receiving media coverage from the national and international mainstream media. While this was happening, a communicative battle was also occurring between two distinct political discourses: those that were being raised by the EZLN and their delegates against the government; and political parties' views about the Zapatistas' demands (López and Chihu 2008).

A second example is the "Other Campaign" [La Otra Campaña] during the 2006 presidential and federal elections. Again, a delegation led by Subcomandante Marcos went out of Chiapas, but on that occasion the EZLN delegates created a national campaign focusing on indigenous towns and grassroots movements designed to hear from marginal communities regarding their struggles, and to set a counterpolitical agenda. Once more, the global, national and local call generated a 'caravan' of free media to cover those activities that were passed over by mainstream media. In contrast with "Earth's Colour March", the "Other Campaign" was almost invisible for the mainstream media, ${ }^{5}$ even though this campaign lasted longer and the movement took place at a national scale. In relation with the community/citizen media productions generated by this experience, for example, Subcomandante Marcos had a weekly radio programme in the Mexico City no-licence station Ké Huelga, ${ }^{6}$ and that programme was retransmitted by other citizen/community media around the country thanks to podcasting technology. Since then, different community media that were operating without licences started to operate as a network, sharing different content related to the "Other Campaign" and other popular struggles around the country.

Those calls generated an interest for different sectors of Mexican civil society to create visible different expressions of free/popular/alternative/citizen media. The main aim was twofold: on one hand, to claim again that the MCS was incomplete and did not cover the different expressions of Mexican society; on the other, to push a political-cultural process for building citizenship through communication and information activism from the bottom up.

In sum, the Zapatista Intervention impacted two parallel areas: at the institutional level with the San Andrés accords, which addressed the right to access and operate media for native towns at the Constitutional level, and at the grassroots level by generating organisational and meeting spaces for citizen/community/popular media collectives so they could share communicative experiences and knowledge gathered during the Zapatistas' calls and mobilisations. Thus, the Zapatista intervention has been an important agent in the three communicative battles: a) recognition of the sector of citizen/community media; b) exercise of the freedom of expression; and c) access to licences.

${ }^{5}$ During the political campaign, however, Subcomandante Marcos was interviewed for the first time by Televisa on a daily news programme after the Atenco repression. The interview (9 May 2006) can be seen here: https://www.youtube.com/watch?v=irLRvbl3qpc. Because of the repression that occurred, Marcos as "Zero Commander" stayed in Mexico City for a period of two months in solidarity with the Atenco victims.

6 This citizen radio began in the context of the student strikes in the National Autonomous University of Mexico (UNAM) in 1999, and it is still operating without licences. Students and anarchist collectives operate this citizen/radical media. For more information, see Castillo (2009). 


\section{Intensified Struggles}

\subsection{The Grassroots Experiences and Citizen Media Spin-Offs}

As a complex and unequal society, Mexico has experienced different protests and social movements that have provoked communicative experiences during the first two decades of the twenty-first century. These include Frente de Pueblos en Defensa de la Tierra (FPDT), Asamblea Popular de los Pueblos de Oaxaca (APPO), \#YoSoy132, \#TodosSomosIPN, Movimiento por la Paz y Dignidad, \#Ayotzinapa and \#Nochiztlan. The common denominator among these is the lack of coverage from the mainstream media; when the first sector of the media covered these events, it largely portrayed them in a negative light. ${ }^{7}$ Thus, the concentrated MCS constantly reflects its undemocratic structure, particularly in terms of these left-wing activities and expressions. However, at the same time, as Rovira documented and established with empirical research, these experiences have been crucial for breaking the dominance of the mainstream media and triggering some kinds of communication 'spin-off' experiences. Rovira states: "The - free - media in hands of activists, in the effervescent moments they became open spaces, broke with the logic of their formats and genders: they put the microphone or the camera to everyone in the field" $(2013,53)$.

These experiences of the citizen media in the context of social movements or protests have triggered interesting collective communicative knowledge and communicative cultures that have been shared at the grassroots level.

In parallel to those social struggles and experiences, and in relation to the everyday life of the different sectors of the Mexican civil society, Calleja and Solis (2007) have observed that the interest of citizens in boosting citizen/community radio spaces and in speaking for themselves has been an important part of democratic progress in Mexico. There is an understanding of the importance of promoting a political culture of respect and tolerance where one is able to express one's views to society by producing and generating proposals in these alternative non-profit spaces.

\subsection{International Support}

It is important to add that at the international level, the Organization of American States (OAS) and United Nations institutions such as the Food and Agriculture Organization (FAO), Development Program (UNDP), and the Human Rights Council have actively promoted the citizen/community media agenda in the national communication policies in the region. For example, Frank La-Rue, in his report as Special Rapporteur of the UN on the promotion and protection of the right to freedom of opinion and expression, recommended the following in 2010:

Protecting disadvantaged social groups' right to freedom of expression requires Governments to create a legal framework for telecommunications which is based on democratic principles and which seeks to provide access to all sectors of society. Community-based media should serve as a tool for local communities and should be representative of their diverse interests. (La-Rue 2010,11)

${ }^{7}$ It will be impossible in this paper to describe and analyse these experiences; however, for in-depth information see Gravante (2012), Gómez and Treré (2014), Rovira (2013), and Treré and Cargnelutti (2014). 
At regional level, Carolina Botero, as Special Rapporteur for freedom of expression of the Inter-American Commission of Human Rights, evaluated the degree of pluralism and diversity in broadcasting in Mexico, and recommended the following in her 2010 report to the Mexican state:

- Adopt a legal framework that provides legal certainty, promotes the diversification of radio and television, and contributes to the creation of a media market that is pluralistic and accessible to all sectors of the population, especially community broadcasting.

- Guarantee that the allocation of radio or television licences be fully, clearly, and transparently regulated by law, based on criteria that are objective, clear, public, and democratic.

- Establish a public body to regulate radio and television that is independent of the government.

- Establish legal mechanisms to guarantee that the transition to digital broadcast services guarantees the greatest plurality and diversity possible in the use of the spectrum [...] $(2010,282)$.

These reports represented significant inputs to the national media policy debates in the region, and particularly to media reform advocates, because those advocates were given documents and arguments from the UN and OAS that they could use in different forums and debates with legislators, policy makers and private communication industry lobbies. As such, they helped to achieve important goals in relation to the idea of opening up the spectrum and awarding licences to the third sector of the media as a positive and democratic sign of freedom of expression for Latin American countries and societies from a human rights perspective.

Another key international/regional player that has been promoting media reform and advising Mexican civil society associations and communities or collectives that support or operate citizen/community media outlets is the World Association of Community Radios, a global non-governmental organisation better known as its acronym in French or Spanish: AMARC.

In terms of the process of media reform in Latin America, this research agrees with Hintz, who argued:

[...] that national policy making has to be understood in the context of an international and multi-actor environment. Government constellations, intergovernmental cooperation, multinational norms and pressures, political traditions, ideological change, social mobilizations, and the strategic roles of civil-society organizations as well as individual experts, among many other factors, have framed policy change and created trajectories for understanding policy problems and needs. $(2011,148)$

In Mexico, as in the rest of the region, media reform was expected to represent a major vector in terms of freedom of expression, equal access to all three sectors, cultural diversity, economic competition and better communication services. It is important to underline that the communication/public policies perspective shaping the MCS is 
the market logic under the imperatives of neoliberal, corporate, global capitalism (Gómez 2016).

It is important to establish that the struggle for the legitimation of the community/citizen media in Mexico has been fought in two arenas: in the practical field - operating without licences and occupying the spectrum - and in legal discussion and debates about freedom of expression and plurality. In terms of the latter, the community/citizen media were supported by different national and global NGOs, academics, human rights advocates and some legislators in their fight to obtain legal recognition, against the powerful lobby of the broadcasting industry at the national (CIRT) and international (International Association of Broadcasting [IAB]) levels within the closed Mexican legal framework.

Calleja and Solis (2007) documented in depth the complicated administrative process undergone by 11 community/citizen radio stations to earn their permissions licences under the advice of civil society organisations led by AMARC-México, after dealing with various federal government institutions from 2003 to 2005. It is important to recall that from its beginnings the Fox administration was seen as offering hope of opening up democratic processes after the defeat of the PRI, which had ruled for 70 years. In particular, this was the case with the fight to democratise the Mexican media system with a new broadcasting act. That scenario was not realised, and was one of the significant failures of that administration (Bravo 2011). At the same time, some key actors of the administration were open to pushing forward recognition of the community/citizen stations without licences, and they became allies during those years. For example, this was the case with the director of the Mexican Institute of Radio (IMER), Dolores Béistegui, among others (Calleja and Solis 2007).

These different institutional procedures were not exempt from international hearings in the Inter-American Court of Human Rights (IACHR), where community media advocates and community/citizen radio stations argued that their inclusion in the MCS was a matter of freedom of expression and thus a human rights issue that the Mexican state had to accomplish in accordance with the international standards, conventions and pacts that the country had signed. In that international arena, important global organisations such as the Open Society Foundation supported the legal battles in Mexico, and thus set a precedent in the fight for the democratisation of the media in Mexico and the wider region (Calleja and Solis 2007).

In summary, the discussions taking place at the regional level have been important for informing national media policy debates, especially those in favour of making room for citizen/community media. In this regard, the UN and OAS human rights divisions have been important supranational entities that have helped to amplify the agenda of the Mexican community/citizen media movements in the eyes of the Mexican Government and Legislative Chambers. In addition, AMARC and other international players, such as OSF, have pushed in the same direction.

\section{Limited Legitimation}

The figures related to the structure of the radio broadcasting industry from the 1990s to the beginning of the twenty-first century did not change considerably, remaining static at $88 \%$ of commercial licensed stations versus $12 \%$ with cultural or state licence permissions. That figure did alter in 2010 , when the difference reduced to $77 \%$ versus $23 \%$ (Sosa 2011, 99). That small redress in favour of the permissions can be explained by a combination of three main circumstances: a) the political will of different key politicians; $b$ ) institutional change within the MCS and the democratisation of the Mexican political system; and c) the agency of change pushed forward by com- 
munity radio stations, civil society organisations, advocates and academics. The interaction of these factors generated a small change that has to be acknowledged as a positive development. However, inclusion of the citizen/community media on the airwaves remains problematic. For example, according to Sosa, in 2010 there were 200 radio stations without a licence $^{8}(2011,102)$, and it is important to recall that in the first five years of the twenty-first century, some citizen radio stations obtained their permissions only after surviving a complicated legal process.

Paradoxically, those licences were obtained after a critical and aggressive period of persecution against community/citizen media outlets at around the same time. As Calleja and Solis (2007) underscore, that situation was the spark required to reinforce their legitimate struggle to obtain their licences in the changing democratic climate of those years.

Eleven ${ }^{9}$ citizen/community radio stations finally obtained their licences and gained a place on the spectrum without the guardianship of a government institution like Radios Indigenistas. In 2010, another six community radio stations were granted permissions. Thus, at the end of the first decade of the twenty-first century, there were 19 community/citizen media outlets (Sosa 2011) - the historic community stations Radio Teocelo and Radio Huayacocotla are included in this figure. Notwithstanding this development, after winning this bureaucratic battle Klinger stated that "their legal status was not regulated and there is no transparent way to obtain licences and resources" $(2011,12)$. In some cases, the resources granted to these stations verged on the ridiculous, such as the right to broadcast within only one square $\mathrm{km}$ (Calleja 2011).

Certainly, the cases discussed in this article do not exhaust the richness of the third sector of the media in Mexico. They do, however, give us some scope to understand the different experiences, particularities and processes of the long battles fought to gain spectrum and legal recognition in the MCS.

Before concluding, it is important to address how the Telecommunications and Broadcasting Act of 2014 frames third sector communications/media in order to understand the new institutional legal framework and its limits.

\section{Rewriting the Rules}

The process of media reform and the issuing of the Mexican 2014 Telecommunications and Broadcasting Act must be read in the context of the emerging democratic processes in Mexico and, in a wider sense, at the Latin American level. The region has witnessed many reforms regarding media and telecommunications from two main and differing perspectives - market logic versus communication and social rights - between 2000 and 2017. Thus, in this article's view, the changes in the Latin American communications systems are central to understanding the democratisation processes of the region. In addition, we have to remember that the frameworks used

8 These 200 radio stations are spread around Mexico. They are small and linked mainly to native towns, marginal communities and urban citizen projects that are in need of communication, especially because the other two sectors of the media do not cover them. Gasparello (2012) and Ramos (2007) provide some examples of how these community/citizen radio stations operate.

9 The name of those radio stations are: Radio JenPoj (Oaxaca), Radio Uandhári (Michoacan), Radio Ecos de Manantlán (Jalisco), Radio Nandía (Oaxaca), Radio Cultural FM (Michoacán), Radio Huayacocotlh. La voz de los campesino (Veracruz), Radio Erandí (Michoacán) Radio Calenda (Oaxaca) La Voladora Radio (Estado de México) Radio Bemba FM (Sonora) y Omega Experimental (Estado de México). 
to shape the media systems in Latin America before the reforms were issued by dictatorships or authoritarian regimes (Becerra 2015).

As a point of entry, it has to be said that the new Act of 2014 has been characterised by its privileging of market imperatives over public service mandates or communication rights (Gómez 2016). However, this new legal framework has an important central factor, which is its institutional role to regulate, promote and supervise the use and exploitation of the spectrum in the form of an autonomous and independent public entity called the Federal Institute of Telecommunications (IFT). Thus, this institution is responsible for enforcing the Act and, in the particular case of the third sector of the media, is in charge of setting the technical dispositions of any telecom or broadcasting banding and granting licences. This means the Ministry of Communications and Transports and Ministry of Government are no longer in charge of administrating the radio electrical spectrum (see Article 15 of the Act). Another point to note is that Article 54 established the radio electric spectrum as a public good of the nation, and its ownership and administration belongs to the Mexican state, which corresponds to the IFT.

The other highlight of the new framework in relation to the third sector of media is the concessions - or licences - regime, where finally there is a legal figure for this sector. However, it is important to underscore that the Mexican legislators established the following in Article 66: "A sole concession shall be required to provide all kind of telecommunication and broadcasting public service" (Diario Oficial de la Nación 2014). Therefore, to some extent, this Act suggests the idea of a convergent licence. This is important because the community/citizen actor could apply for a telecommunications concession that is not restricted to radio or TV. ${ }^{10}$ Thus, there is an interesting open door for the third sector to operate convergent networks and services.

The Act considers three types of concessions: commercial, public and social use. The community/citizen actor is described as being for social use, as follows:

For social use: Grants the right to provide for telecommunication and broadcasting services with cultural, scientific, educational or community purposes, with not-forprofit purposes. The community and indigenous concessions are included in this category [...] The concessions for community social use may be granted to civil society organizations that do not pursue or operate for-profit purposes and that are constituted under the principles of direct citizen participation, social coexistence, equality, gender equality and diversity. The concessions for indigenous social use may be granted to the indigenous people and communities of the country according to the guidelines issued by the institute and its purpose shall be the promotion, development and preservation of their languages, culture, knowledge, promoting traditions, internal rules and principles respecting gender equality, and allowing the integration of indigenous women in the participa-

10 In fact, in 2016 the Asociación Civil de Telecomunicaciones Indígenas Comunitarias obtained a licence from IFT to operate a cellular telephone network for communities in Veracruz, Oaxaca, Chiapas, Guerrero and Puebla. Currently this network is operating in 19 communities in the state of Oaxaca with prices for use around 2 dollars per month. 
tion of the purposes for which concession is requested.

(Diario Oficial de la Nación 2014)

The recognition in the Act of community and indigenous social use, given what is included in this research, is a significant step forward in reshaping the MCS; there is finally an explicit place for the third sector of communications in the Mexican communication legal framework. It is only a first step, but it could certainly provide a basis for addressing inequalities and democratising the MCS.

In terms of access to the financial resources required to be sustainable, Article 89 of the Act established narrow possibilities and, in fact, could be seen more as limiting. It reads as follows:

a) Donations in cash or kind; b) contributions or payments;

c) sale products, own contents previously transmitted according to their purpose and object or services; d) resources from public entities for the creation of programming contents other than those of commercialization; e) lease of studios and editing, audio and recording services; f) co-investment agreements with other social means for a better compliance with their purposes of public service, and; g) sale of publicity to the federal public entities which shall destine one per cent of the amount for services of social communication and publicity authorized in their respective budgets to the group of community and indigenous concessions for social use of the country, which shall be distributed equally among the existing concession. (Diario Oficial de la Nación 2014)

The other controversial key issue was the possibility of spectrum allocation and reservation for the third sector, with the idea of following the provisions in place in Argentina, Uruguay, Ecuador and Bolivia (Becerra 2015), where one third of the spectrum is reserved for social use. However, this was not achieved in the Mexican legislation, as seen in Article 90:

[...] The institute shall reserve for community and indigenous FM stations ten per cent of broadcasting band of FM that goes from 88 to $108 \mathrm{Mhz}$. Such percentage shall be granted as concession for the upper part of the referred band. The institute may grant concessions for community and indigenous $\mathrm{AM}$ radio stations in the segment of the extended radio spectrum band that goes from 1605 to 1705 Mhz...(Diario Oficial de la Nación 2014)

This clearly falls short of other Latin American media reform benchmarks, and the spectrum allocated is inefficient and insufficient. Because of articles 89 and 90, five community stations and organisations have launched ten lawsuits, claiming that these provisions put them at a clear disadvantage. 
There have been some expectations and concerns about how the IFT will operate the spectrum in accordance with the Act. The first seven concessions for social use were granted in 2015 by the IFT; as of December 2017, the IFT had granted just 21 community licences, and three indigenous radio licences. During the same period, the IFT has granted 139 commercial use licences - 112 FM and 27 AM - (IFT 2017) and 22 for public service use (see http://www.ift.org.mx/industria/concesionessociales-otorgadas\#).

Up to December 2017, the IFT had reported 58 citizen/community licences in the MCS. We have to remember that 21 of them are part of the Radios Culturales Indigenistas and the other 37 have gained their frequencies and licences at different times during the past 60 years. Although 35 of them have been granted this century, this number is minimal and the third sector remains in the margins and in an unequal position. Furthermore, in 2016, the IFT began an aggressive campaign against radio stations without licences. Thus, it is urgent that the IFT allocate more spectrums, grant more licences and provide administrative information and legal counselling - in their own languages - to those communities and collectives that are occupying the spectrum and exercising their freedom of expression without licences.

\begin{tabular}{|l|c|c|c|c|}
\hline & $\begin{array}{c}\text { Radios Indigenistas } \\
(C D I)\end{array}$ & Indigenous towns & Community & Total \\
\hline Number of radio licences & $21^{*}$ & 6 & 29 & 58 \\
\hline
\end{tabular}

*Even though these radio stations have moved back to a paternalistic government media, at some point they have to migrate towards autonomy from the government and recover their native/community status.

Table 1. Type of licences related with the Mexican third sector of the media. Elaborated by the author with article data from IFT.

In saying this, it is important to give credit to Mexican civil society and those behind the various struggles that have started to break the commercial dominance of the spectrum and licences; this demonstrates, to some extent, their ability to re-shape, little by little, the cumbersome structure of the MCS and the accompanying social power relations. It is clear that the first sector of communication remains in control, but there is a small fracture in their historic structural dominance.

\begin{tabular}{|c|c|c|c|}
\hline $\begin{array}{c}\text { First } \\
\text { (Commercial) }\end{array}$ & $\begin{array}{c}\text { Second } \\
\text { (Public) }\end{array}$ & $\begin{array}{c}\text { Third } \\
\text { (Citizen/Community) }\end{array}$ & Total \\
\hline $1,434(76 \%)$ & $391(20.7 \%)$ & $\mathbf{5 8}(\mathbf{3} \%)$ & $1,883(100 \%)$ \\
\hline
\end{tabular}

Table 2. Number of radio licences allocated to the three media sectors in Mexico (2017). Elaborated by the author with IFT data from http://www.ift.org.mx/industria/concesiones-sociales-otorgadas\# (IFT 2017).

\section{Final Remarks}

Research has established that there are two clear linked trajectories in the structural history of the third sector media in Mexico. One is expressed during protests or the emergence of social movements, and the other runs in the institutional rhythms and everyday timing and battles of the marginal communities using and occupying the spectrum with and without licences across the country. Both trajectories have helped 
in recognising and invigorating the significant role of the third sector of the media in reshaping and opening up the undemocratic MCS. The article underlines that even if the structuration of the MCS is difficult to change and the commercial first sector is still in control, it is important to emphasise how people make use of communication to increase their own communicative power to shape and reshape social structures. At the same time, this research underlines the importance to generate public spheres through the third sector of the media to enrich or generate democratic practices and freedom of expression in Mexico.

Furthermore, the citizen/community media has to be thought of as exercising old and new communication and information practices; these media need radio spectrum and licences for covering marginal communities across the country and, at the same time, they need to produce content that provides a community service for both local and translocal communities that can re-distributed via the Internet on a global scale.

In the case of the IFT, it is clear that it has not accomplished all the mandates established in the 2014 Act, particularly in regard to indigenous towns and community media. In the case of the former, the IFT has only granted three licences since the new Act and, in the case of the latter, the figures are unreliable. In contrast, the power and centrality of the commercial stations clearly reflects that the IFT's priority is the first sector.

In addition, it must be emphasised that this research confirms that the processes concerned with "national policy making [have] to be understood in the context of an international and multi-actor environment" (Hintz 2011), particularly the legal battles that the third sector of the media have faced in order to be recognised in Mexico. In this respect, the broader context of similar media reforms within the Pink Tide movement in Latin America, to some extent, helps to understand the debates and priorities of the Mexican third sector.

Finally, it is clear that the new Mexican Telecommunications and Broadcasting Act is insufficient for the third sector of communication. However, the sector is recognised and has some legal standing, which may offer the potential to open up a small fracture in the structure of market-oriented Mexican Communication System.

\section{References}

Artz, Lee, ed. 2017. The Pink Tide: Media Access and Political Power in Latin America. London: Rowman and Littlefield.

Atton, Chris. 2015. The Routledge Companion to Alternative and Community Media. Routledge: New York.

Badillo, Ángel, Guillermo Mastrini and Patricia Marenghi. 2015. Teoría crítica, izquierda y políticas públicas de comunicación: el caso de América Latina y los gobiernos progresistas. Comunicación y sociedad 24: 95-126.

Becerra, Martín. 2015. De la concentración a la convergencia. Políticas de medios en Argentina y América Latina. Paidós: Buenos Aires.

Beltran, Luis Ramiro.1976. Políticas nacionales de comunicación en América Latina: los primeros pasos. Nueva Sociedad 25: 4-34.

Botero, Carolina. 2010. Report of the Office of the Special Rapporteur for Freedom of Expression. Washington DC: OAS-IACHR. Accessed 4 August, 2016. http://www.oas.org/en/iachr/expression/docs/reports/annual//nfornme\%202010\%20P\%20 ENG.pdf

Bravo, Jorge. 2011. El presidencialismo mediático. Medios y poder durante el gobierno de Vicente Fox. México: Guernika-UNAM.

Calleja, Aleida. 2016. La crisis de la Radio Indigenista. La Silla Rota. Accessed 1 March, 2018. https://lasillarota.com/opinion/columnas/la-crisis-de-la-radio-indigenista/102028 
Calleja, Aleida. 2011. Medios comunitarios: incertidumbre jurídica y criminalización. In Panorama de la comunicación en México, edited by Jorge Bravo, Aimeé Vega and Raúl Trejo, 241-253. Ciudad de México: AMEDI.

Calleja, Aleida and Beatriz Solis. 2007. Con permiso. La radio comunitaria en México [Second edition]. México: Fundación Friedrich Ebert-México/AMEDI.

Castells, Manuel. 2015. Networks of Outrage and Hope: Social Movements in the Internet Age. New York: John Wiley \& Sons.

Castells-Talens, Antoni. 2011. ¿Ni indígena ni comunitaria? La radio indigenista en tiempos neoindigenistas. Comunicación y Sociedad 15: 123-142.

Castells-Talens, Antoni and Juan M. Ramos. 2013. Technology for cultural survival: Indigenous-language radio at the end of the twentieth century. In Technology and Culture in Twentieth Century Mexico, edited by Araceli Tinajero and Brian Freeman, 178-193. Tuscaloosa: Alabama University Press.

Castillo, José. M. 2009. La Ké Huelga Radio: Reflejo de un medio alternativo en México [Doctoral dissertation]. Instituto Tecnológico y de Estudios Superiores de Monterrey, Campus Ciudad de México.

Cornejo, Inés. 2010. La radio cultural indigenista en México: Dilemas actuales. Revista Mexicana de Ciencias Políticas y Sociales 52 (209): 55-66.

Dahlgren, Peter. 2006. Doing citizenship: The cultural origins of civic agency in the public sphere. European journal of cultural studies 9 (3): 267-286.

del Val, José, Juan Mario Pérez, and Juan Manuel Ramos. 2010. Voces del sistema de radiodifusoras culturales indigenistas: audiencia y programación en cinco emisoras. México: CDI-UNAM-BUAP.

Diario Oficial de la Nación. 2014. July 14. Accessed 20 April, 2017. http://www.dof.gob.mx/nota detalle.php?codigo=5352323\&fecha=14/07/2014

Diario Oficial de la Nación. 2001. August 14. Accessed 17 March, 2017. http://www.dof.gob.mx/nota detalle.php?codigo=762221\&fecha=14/08/2001

Downing, John D. 2001. Radical Media: Rebellious Communication and Social Movements. London: Sage.

Downey, John, and Natalie Fenton. 2003. New media, counter publicity and the public sphere. New Media \& Society 5 (2): 185-202.

Federal Institute of Telecommunications [IFT]. 2017. Industria [web page]. Accessed 05 April, 2018. http://www.ift.org.mx/industria/concesiones-sociales-otorgadas\#

Fraser, Natalie and Axel Honneth, eds. 2003. Redistribution or Recognition? A Political-

Philosophical Exchange. London: Verso.

Fuchs, Christian. 2015. Culture and Economy in the Age of Social Media. London: Routledge.

Gasparello, Giovanna. 2012. No morirá la flor de la palabra... La radio comunitaria indígena en Guerrero y Oaxaca. Nueva antropología 25.77: 133-154.

Golding, Peter and Graham Murdock. 2000. Culture, communications and political economy. In Mass Media and Society [Third edition], edited by Michael Gurevitch and James Curran, 70-92. London: Edward Arnold.

Gómez, Rodrigo. 2016. Communication industries in North America after 20 years of North American Free Trade Agreement: Media policy, regulatory bodies and concentration. The International Communication Gazette 78(3): 177-199.

Gómez, Rodrigo, and Emiliano Treré. 2014. The\# YoSoy132 movement and the struggle for media democratization in Mexico. Convergence 20(4): 496-510.

González, Pablo. 2013. Capitalismo corporativo y ciencias sociales. Crítica y Emacipación 9: 23-42.

Gravante, Tomasso. 2012. Ciberactivismo y apropiación social. Un estudio de caso: la insurgencia popular de Oaxaca. Sociedade e Cultura 15 (1): 51-60.

Habermas, Jürgen.1996. Between Facts and Norms. Cambridge: MIT Press. 
Hallin, Daniel and Stylianos Papathanassopoulos. 2002. Political clientelism and the media: Southern Europe and Latin America in comparative perspective. Media, Culture \& Society 24 (2): 175-195.

Hayes, Joy E. 2018. Community media and translocalism in Latin America: Cultural production at a Mexican community radio station. Media, Culture \& Society 40 (2): 267-284.

Hintz, Arne. 2011. From media niche to policy spotlight: Mapping community-media policy change in Latin America. Canadian Journal of Communication 36 (1): 147-156.

Howley Kevin, ed. 2009. Understanding Community Media. London: Sage.

Instituto Nacional Indigenista. 1995. Instituto Nacional Indigenista 1989-1994. México: INI.

Kaplún, Mario. 1985. El comunicador popular. Quito: Ciespal.

Khalil, Joe and John D. Downing. 2016. Shift or stasis: Questioning global communication power - Introduction. International Journal of Communication 10: 8. Accessed 4 April, 2017. http://ijoc.org/index.php/ijoc/article/view/4807

Kingler, Ulrike. 2011. Democratizing media policy: Community radios in Mexico and Latin America. Journal of Latin American Communication Research 1 (2): 1-19.

La-Rue, Frank. 2010. Report of the Special Rapporteur for Freedom of Expression of the United Nations. Mr. Frank La-Rue. Human Rights Council. General Assembly United Nations. Accessed 4 August, 2016. https://documents-ddsny.un.org/doc/UNDOC/GEN/G10/130/52/PDF/G1013052.pdf?OpenElement

López, Alejandro, and Aquiles Chihu. 2008. El Procesamiento Sìmbólico De La Protesta: El Discurso De Opinión En Torno a La Marcha Del Color De La Tïerra. Estudios Sociológi$\cos 26$ (78): 695-723.

Magallanes, Claudia. 2011. Zapatista Media (Mexico). In Encyclopedia of Social Movement Media, edited by John D. Downing, 563-565. Los Angeles: Sage.

McQuail, Dennis. 1992. Media Performance: Mass Communication and the Public Interest. London: Sage.

Mejía, Fernando. 1989. La industria de la radio y la televisión y la política del Estado mexicano. 1920-1960. Vol. 1. México: Fundación Manuel Buendía.

Meneses, María E. and Jorge Bravo, eds. 2015. Telecomunicaciones y radiodifusión en la encrucijada. Regulación, economía y cambio tecnológico. San Luis Potosí: FontamaraUASL.

Milan, Stefania. 2010. Medios comunitarios y regulación. Una perspectiva de comunicación para el desarrollo. Investigación \& Desarrollo 14 (2): 268-291.

Mosco, Vincent. 2009. The Political Economy of Communication [Second edition]. London: Sage.

Mtimde, Lumko, Marie-Hélène Bonin, Nkopane Maphiri, and Kodjo Nyamaku. 1998. What is Community Radio? A Resource Guide. AMARC Africa and Panos Southern Africa: South Africa. Accessed February 3, 2016.

Ortega, Patricia. 2006. La otra televisión. Por qué no tenemos televisión pública. Ciudad de México: UAM-Xochimilco.

Ramos, Juan M. 2016. Radio, cultura e identidad: 10 tesis sobre la radio indigenista mexicana. In Miradas propias. Pueblos indígenas, comunicación y medios en la sociedad global, edited by Juan M Ramos and Claudia Magallanes, 179-194. Quito: Ciespal-UIA Puebla.

Ramos, Víctor M. 2007. "La radio comunitaria frente a los grupos de poder." Razón y Palabra 12.59.

Reyes-Matta, Francisco. 1983. Comunicación alternativa y búsquedas democráticas. MéxiCO: ILET.

Rodríguez, Clemencia. 2009. De medios alternativos a medios ciudadanos: Trayectoria teórica de un término. Folios 21/22: 13-25.

Rodríguez, Clemencia, Dorothy Kidd and Laura Stein. 2009. Making our media: Global initiatives toward a democratic public sphere. Vol. 1 Creating New Communication Spaces. Cresskill, NJ: Hampton Press. 
Romo, Cristina. 1990. La otra Radio. Voces débiles, voces de esperanza. México: Fundación Manuel Buendía /IMER.

Rovira, Guiomar. 2013. Activismo mediático y criminalización de la protesta: medios y movimientos sociales en México. Convergencia 20 (61): 35-60.

Rovira, Guiomar. 2014. Zapatistas sin fronteras: Las redes de solidaridad con Chiapas y el altermundismo. Mexico: Ediciones Era.

Sáez, Chiara. 2008. Tercer sector de la comunicación. Teoría y praxis de la televisión alternativa. Una mirada a los casos de España, Estados unidos y Venezuela. PhD Thesis, Universidad Autónoma de Barcelona, Spain.

Soledad Segura, María and Silvio Waisbord. 2016. Media Movements: Civil Society and Media Policy Reform in Latin America. London: Zed Books.

Smith, Peter H. 2001. El imperio del PRI. Panorama de la economía, la sociedad y la política de la posguerra. In: Timothy Anna, Jan Bazant, Friedrich Katz, John Womack, Jean Meyer, Alan Knight, Peter H. Smith, eds. Historia de México. Crítica: Barcelona, pp. 321-384.

Sosa, Gabriel. 2011. Grupos radiofónicos y concentración. In Panorama de la comunicación en México 2011. Desafíos para la calidad y la diversidad, edited by Jorge Bravo, Aimée Vega and Raúl Trejo, 97-114. Ciudad de México: AMEDI.

Sosa, Gabriel. 2009. México. In Las mordazas invisibles. Nuevas y viejas barreras a la diversidad en la radiodifusión. AMARC, 169-198. Buenos Aires: AMARC-ALC.

Treré, Emiliano and Daniele Cargnelutti. 2014. Social Movements, Social Media and Web 2.0: The Case of the Movement for Peace with Justice and Dignity. Comunicación y Sociedad 27(1): 183.

Woldenberg, José. 2015. La democracia como problema (un ensayo). Ciudad de México: El Colegio de Mexico.

\section{About the Author}

\section{Rodrigo Gómez}

Rodrigo Gómez is Professor in Communication Policies and Industries, he co-coordinates the Observatory of Cultural Industries, Policies and Consumes in the Metropolitan Autonomous University (UAM) in Mexico City. He was visiting scholar at University of Leeds (2010), McGill University (2008) and University of Oregon as Fulbright (2013-2014). He is currently chair of the Political Economy Section of the International Association of Media and Communication Research (IAMCR). 